\title{
The Philippines-Hong Kong Corridor
}

Movement of workers between the Philippines and Hong Kong has been a stable feature of Filipino labour migration since the 1970s. Most migrants in this corridor are domestic workers. Of the world's estimated 53 million domestic workers, $83 \%$ female, and $41 \%$ of them work in the AsiaPacific (ILO, 2013). Hong Kong is unique destination in that the city-state recognises domestic work as 'work', requires migrants and employers to sign a contract.

In Hong Kong, the contract specifies that the migrant must live in the employer's home and sets their minimum monthly wage (currently HKD \$4520.) Employers of Foreign Domestic Workers in Hong Kong must provide a food allowance of $\$ 1075$ or free food and free accommodation.

Employers are required to set agreed working hours and days off, observe holidays, offer coverage for medical expenses, and pay for the migrant's return home at the end of the contract (Government of Hong Kong, 2019). Domestic workers can complete multiple contracts, but are not permitted to apply for a Hong Kong residency card. Domestic worker migrants can thus reside in Hong Kong for decades but cannot settle in the city.

The number of Filipino migrants in Hong Kong has remained relatively steady - 158,000 in 1997 and 201,000 in 2013, with the vast majority being women on temporary domestic work contracts (POEA, 2013). Many Filipino migrants have some tertiary education but were underemployed in the Philippines, unable to find work commensurate to their qualifications (Scalabrini 2013,123-30). Though the work Hong Kong offers is low-status, it come with relatively transparent salary and contract provisions, public freedoms, social life and close communications with the Philippines.

While the numbers of migrants going to Hong Kong have been overtaken by numbers leaving for other destinations for construction, medical or carework, Hong Kong has remained a top destination for Filipino domestic workers. At the same time, the labour market in Hong Kong has shifted to incorporate more migrants of other nationalities, especially Indonesians. Following the historical trajectory described by Constable (2007), Filipinos replaced Chinese amahs (maids) because they were considered more tractable; now Filipinos are considered more demanding and less tractable than Indonesians. Filipinos are also considered more capable of taking on complex, additional tasks that extend their role beyond domestic work in a city short of labour.

\section{Exploitation}

Migrants experience exploitation in all live-in domestic worker migration schemes. Hong Kong is no exception. Long hours, emotional labour, lack of privacy, loss of personal life, intrusion on personal space and activities are concomitant with living in a workspace that is also the employer's home and the migrant's place of residence (Constable, 2007). Workers regularly report nonpayment of wages - salary deductions for spurious reasons, lack of a day off, insufficient food, and employers 'holding' the migrant's passport. These circumstances were once frequent, but are now less common, largely due to activist campaigns and the presence of several Filipino and international NGOs which assist migrants in distress (Constable, 2009).

Migrants and would-be migrants from the Philippines compare experiences in destination countries and choose according to both conditions and their means. It is more expensive, in terms of visa fees and agency fees, to find a placement in a 'good' country. In the hierarchy of Filipino domestic worker migration destinations, Hong Kong is reputed to be less awful than Singapore, Taiwan, and Israel, the Gulf or Jordan and Greece (McKay, 2012). The city offers relatively more freedoms and better salaries for Filipinos (Constable, 2007). While salaries and working conditions for domestic workers may be better in France or the UK, access to that work now usually means following an irregular strategy (McKay, 2016). Canada is usually better than Hong Kong or Europe, with a route 
to permanent resident status, but there are a surprising number of 'bad employers' in Canada who force migrants to work 'shared' between households or outsource them to other work etc., as they do in Hong Kong (McKay, 2012). Exploitation of domestic worker visa-holders in other labour sectors is not uncommon around the world. In Hong Kong, some employers have forced their domestic workers to work in retail outlets of factories on the weekends, for example. But exploitation is not always the outcome; domestic workers operate in a complex environment with many hidden (and irregular) opportunities for earning or changing work and workplaces.

Filipino migrants who remain in Hong Kong long-term thus tend to be comparatively entrepreneurial. The city experiences labour scarcity at the lower end of the job market, so cash-inhand and part-time work that tops up a maid's salary is common. Filipinos call this 'aerobics' taking multiple part-time jobs. This means breaking the formal conditions of their contract to work, part-time, for additional employers doing cleaning, pet care, babysitting or other work. Hong Kong's domestic worker contract can even conceal work in accounting or managing home renovations (McKay, 2012). Doing 'aerobics' can raise migrants' salaries well above the government-stipulated minimum rate (Gibson, Law and McKay, 2001). Some migrants also find work in the service sector, including the nightime entertainment economy of Wanchai.

While many Filipino migrants initially understand the city as gateway to their eventual onmigration to third countries, Hong Kong's informal sector opportunities entice them to stay. The city thus has a significant population of long-term Filipino migrant workers and a social infrastructure that supports them.

\section{Public life and development}

Hong Kong offers informal spaces where migrants can to socialise and share information. 'Central' is the business district of Hong Kong Island, a centre of high-rise office buildings with luxury goods outlets in their bottom-floor malls. Each Sunday, streets and parks of the Central district fill with Filipino migrants. This Filipino gathering extends into the open spaces under several of the city's major office buildings. Here, migrants are tolerated, rather than invited per se. Protests require official permissions from the Hong Kong government, but spontaneous socialising is accepted, with the clean-up costs for this day of migrant sociality borne by the city. Filipino domestic workers are generally tolerated but not welcomed into Hong Kong's public spaces during the working week. On Sunday afternoons, however, they are allowed take over the heart of the city.

Beginning mid-morning, small groups put down picnic blankets around Central's Star Ferry terminal, on Statue Square, under the headquarters of the Hong Kong and Shanghai Bank, and in the Chater Gardens park. As the day goes on, more women emerge from churches and public transit to join in. They sit and exchange news, gossip, food, and money late into the evening. NGOs representing migrant groups, Philippine municipal mayors looking for the overseas workers' vote, consular officials, and researchers all visit workers here. These people would usually be inaccessible, attending to their work in private homes, doing the shopping, or shepherding charges to and from school but, on Sunday, they are free. Mobile Chinese vendors arrive to sell food and drink and Filipinos offer each other services: manicures, pedicures, haircuts, phone-credit top-ups and the like. Filipinos in Hong Kong are at their most anonymous and most comfortable in this crowd.

For Filipinos, the word 'Central' describes both the city district and their Sunday gathering itself (McKay, 2012). Their social space is laid out by province, municipality and then village. For example, migrants from Benguet Province congregate under the HSBC building near the escalators. Ask at their picnic blankets and they can point you not only to groups from each of the province's municipalities but also the gathering spots for migrants from neighbouring provinces, Ifugao and 
La Union. During the gathering, migrants compare notes on their remittance plans and investment strategies back home. Businesses in Central not only offer these migrants remittance services and banking in the Philippines, they advertise house-and-land packages, agricultural equipment, furniture, and cars on instalment. These services are discussed and marketed, person-to-person, in the gathering. Beneficiaries of NGO training schemes or church-sponsored skills-building activities also report back on their experiences. At the same time, people in the gathering share photographs and make phone calls, send texts, or chat online with kin and friends back in the Philippines, drawing the two nations into a single, translocal social space.

Central as the translocal social corridor connecting Hong Kong to the Philippines is where the individual, intimate and collective work of 'doing development' through migration happens. Families send in their requests for loans and allowances to migrant workers, report on schoolwork and house-building or agricultural projects. By sending back Hong Kong dollars in response, migrants express their complex feelings of obligation, alienation, love and homesickness engendered by long separations (McKay, 2007.) At the same time, migrants compare notes and complain to each other. Central not only lets migrants offer support and advice to each other in face-to-face sociality, it enables them to assess the successes and failures of transnational relationships, whether that's parenting, marriage, or ties mediated through their broader family obligations.

Central's Sunday gathering also facilitates political organising and access to migrants for advocacy groups. These groups are powerful advocates for and opinion leaders among migrants in Hong Kong and in the Philippines (Constable, 2009; Hsia, 2009; Law, 2003) show. Migrants are able to vote in Philippine national elections and shape politics back home through their financial and social remittances. Migrants engagement with activism in Hong Kong goes on to shape their politics on return to the Philippines and that of their families (Rother and Kessler, 2016). In this aspect, Filipino Central is also a training ground for development and activism.

\section{Obstacles to remittance-led development}

Central offers a spatial and temporal site to target initiatives designed to facilitate remittance-led development. Filipino civil society groups focussed on development have long operated branches offices in Hong Kong and sent staff over to work with migrants to shape their investment and business strategies (Gibson, Law and McKay, 2002). Other service-oriented groups offer migrants in-depth training on financial management.

Just as women's migration is often debt-financed - relying on loans or mortgages to pay placement fees - so, too, are remittances from Hong Kong. Most migrants needed to work for up to a full year to pay off their recruitment debt, all the while fielding requests for additional funds from their family. When faced with emergencies or what seemed to be urgent investment opportunities, migrants often negotiate unsecured loans from Hong Kong finance companies against their salaries (McKay, 2012). Having borrowed the maximum amount and failing to service their loans, they turn to their employers for advances or borrow additional funds from other migrants who have savings in the bank. Hong Kong thus has an extensive secondary market for credit and credit agencies often harass migrants' employers and friends for repayment. Loan-sharking among migrants themselves is also prevalent. Extortionate interest rates and transfer fees in the Hong Kong-Philippines corridor eat into the value available for migrants' to invest at home.

Locating sites of productive investment and managing projects from a distance is a huge challenge for migrants (McKay 2012, McKay 2016), despite new communications technologies. In a recent project with migrant clients of Enrich, an NGO specialising in training migrants in financial literacy, our research team found Filipino migrants considered their biggest obstacle to successful 
development investments to be their family's lack of financial acumen (See: curatingdevelopment.com).

Our project worked with 24 of Enrich's clients. With an average age of 45 years, they were each remitting approximately $£ 300$ per month. Before engaging with Enrich, most of their money had been going to school fees and home improvements, as well as status-building gifts for family members and food for celebrations. While it was vital for migrants to share their success with those they love, it was also evident that their lack of a savings buffer or productive assets forced them to turn to finance agencies when faced with an emergency. Moreover, they were putting very little aside, if anything, for investments that would generate ongoing income on their return to the Philippines. Attending Enrich's financial training workshops changed the ways they understood both their own salaries but also their family obligations. Enrich's programme enabled them to give themselves permission to save and to invest in themselves and for themselves.

The alternative to strategic investment is returning as a 'one-day millionaire.' Without an investment strategy and a portfolio of activities, many Filipino domestic worker migrants in Hong Kong-based take successive contracts, working in the city for $15-25$ years. They return home hoping that the beneficiaries of their gifts, school fees, and house renovations will to support them in their old age. Migrants in the Enrich group knew this was not a secure strategy. However, they needed courage and strong arguments to deprive their families of the short-term pleasures of consumer goods and celebratory meals. Once they had given themselves permission to save and invest, they made not only individual investments but identified collective and community-based projects. These were projects such as community water tanks to irrigate agricultural land and supply domestic water. Collective planning and management was more easily undertaken by women who met each other in Central each week.

Interest rates and transactions costs combined with low wages and little opportunity for wage rises dampen remittance-led development. Those factors aside, the largest obstacle for migrants seeking to invest is the dearth of viable project ideas. Returning migrants, often college-educated and former professionals, encounter government training offers that don't match their experience or the scope of their earnings and ambitions. Research participants with whom I have remained in contact report that investment and business advice for returnees is sorely lacking. Having given up a careering in teaching or similar to become a domestic worker in Hong Kong and remitting $£ 50,000$ or more back to the Philippines, the reintegration training they access on their return doesn't meet their ambitions.

Government reintegration programmes tend to offer returnees skills such as baking cookies, sewing, repairing shoes and umbrellas, and managing a small piggery. These activities are typically already familiar to returnees and only suitable as 'sidelines' that generate a small bit of extra income. There's little training available in the skills they'd need to take advantage of emerging digital business opportunities or on what would be required to launch a larger-scale enterprise. The development need, then, is to consider domestic workers as an incipient owner of small-to-medium enterprises. Migrants need appropriate training on finances and management, and the Hong Kong corridor is an ideal incubator to pilot and text accessible, well-targeted schemes and measure their development effects.

\section{Conclusion}

Hong Kong offers Filipinos opportunities and that's why they remain. Even with the challenges outlined here, many choose to stay. The city offers migrants comparatively secure and dignified working conditions, which, when combined with its proximity to the Philippines, can make further risk-taking seem unwise. Should something go wrong, migrants perceive they'll be able to rely on 
fellow Filipinos for support and easily return home. This imagined ease of work and travel is compared to Singapore, Malaysia, Taiwan and the Arabian Gulf, which offer much lower wages and greater isolation. The comparative ease of return between contracts and for vacations during contracts enables migrants in Hong Kong to exert greater influence and control over the ways in which their remittances are invested in the Philippines. Being able to direct and monitor investments is crucial to migrants' wellbeing, as is the sense of camaraderie in the Filipino social life of the city. Moreover, in a city where labour is scarce, lucky long-timers have been able to transition their work, if not their domestic worker visa, into new and more remunerative roles in the informal economy. Thus Hong Kong is a place where a canny migrant can find opportunity and establish networks of support that, despite the nature of the work and the attached social status of 'maid', make their sojourns worthwhile.

\section{References}

Asis, M. (2013) "Here Today and Tomorrow: Transnational Domestic Workers" Asia Research Institute, Singapore at: https://www.youtube.com/watch?v=4Q1Pkqsstgo

Constable, N. (2007) Maid to order in Hong Kong Cornell University Press, Ithaca

Constable, N. (2009) "Migrant workers and the many states of protest in Hong Kong" Critical Asian Studies, 41(1): 143-164

Gibson, K., L. Law Lisa and D. McKay (2001) "Beyond Heroes and Victims: Filipina Contract Migrants, Economic Activism, and Class transformations" International Feminist Journal of Politics, 3(3), $365-386$

Government of Hong Kong 2019. Recruitment: Hiring Foreign Domestic Helpers. Available at: https://www.gov.hk/en/residents/employment/recruitment/foreigndomestichelper.htm

Hsia, Hsiao-Chuan (2009) "The making of a transnational grassroots migrant movement in Hong Kong: a case study of Hong Kong's Asian Migrants' Coordinating Body" Critical Asian Studies, 41(1): 113-141

International Labour Organisation (2013) Domestic workers across the world. Geneva: ILO. Available at: https://www.ilo.org/public/libdoc/ilo/2013/113B09_2_engl.pdf

Law, Lisa 2003 Transnational cyberpublics: new political spaces for labour migrants in Asia. Ethnic and Racial Studies 26(2): 234-252.

Kessler, Christl and Rother, Stefan, 2016. Democratisation Through Migration. London: Lexington Books.

McKay, Deirdre. (2007) Sending dollars shows feeling: emotions and Economies in Filipino migration. Mobilities 2(2), 175 - 194.

McKay, Deirdre. (2012) Global Filipinos. Bloomington: Indiana University Press.

McKay, Deirdre. (2016) Archipelago of Care. Bloomington: Indiana University Press.

Philippines Overseas Employment Agency. Stock Estimates.

https://cfo.gov.ph/downloads/statistics/stock-estimates.html (Last accessed 30/01/2019) 
Scalabrini Migration Centre 2013 Country Migration Report: The Philippines 2013. Prepared for the International Organisation for Migration. Available at:

https://www.iom.int/files/live/sites/iom/files/Country/docs/CMReport-Philipines-2013.pdf. See pp $123-130$. 